\title{
Is There Any Relationship Between the Clinical, Radiological and Histopathologic Findings in Sinonasal Polyposis?
}

\author{
Sinonazal Polipozisde Klinik, Radyolojik ve Histopatolojik Bulgular \\ Arasında İlişki Var mı?
}

Ercan AKBAY' ${ }^{1}$, Tümay ÖZGÜR² ${ }^{2}$ Yaşar ÇOKKESER ${ }^{1}$

Department of ${ }^{1}$ Otorhinolaryngology and ${ }^{2}$ Pathology, Mustafa Kemal University, Faculty of Medicine, HATAY, TURKEY

\begin{abstract}
Objective: The aim of this study was to assess the relationship between clinical, radiological and histopathological findings in nasal polyposis.

Material and Method: This was a retrospective study of 85 patients with nasal polyposis who were treated by endoscopic sinus surgery between the years of 2005 and 2010. All patients underwent preoperative paranasal sinus Computerized Tomography scan in the coronal plane and these images was evaluated with Lund-Mackay scores. The biopsy materials diagnosed as nasal polyp were identified by archive scanning at the pathology department. The Haematoxylin-Eosin stained preparations of the biopsy materials were re-evaluated. All of the results were analyzed by using the SPSS 13.0 software program. Statistical significance was determined as p-value $<0.05$.
\end{abstract}

Results: When the patients with (16.4\%) and without (83.6\%) bronchial asthma were compared regarding the eosinophil, lymphocyte, neutrophil, macrophage, mast cells and goblet cells/ epithelial cell rate, no statistical significance was found $(\mathrm{p}>0.05)$. There was a positive relationship between the preoperative complaint durations and the total Lund-Mackay scores $(r=0.270, p=0.012)$. The neutrophil amount $(16.53 \pm 19.87)$ on the preparations of the patients with metaplasia was higher than the neutrophil amount $(8.71 \pm 23.98)$ on the preparations of the patients without metaplasia $(\mathrm{p}=0.001)$. Radiologically, there was a positive correlation between the infiltration of anterior-posterior sinuses by the polyp tissues and the Lund-Mackay score of the nasal cavity.

Conclusion: There was a positive correlation between preoperative complaint duration and squamous metaplasia; and there was also a positive correlation between the preoperative complaint duration and the total Lund-Mackay score. There was no histopathological difference between the polypoid infiltration of the front and rear group sinuses.

Key Words: Nasal polyps, Pathology, Eosinophils, Tomography

\begin{abstract}
ÖZ
Amaç: $\mathrm{Bu}$ çalışmanın amacı nazal polipli hastalarda klinik, radyolojik ve postoperatif histopatolojik bulgular arasındaki ilişkiyi değerlendirmektir.

Gereç ve Yöntem: 2005-2010 yılları arasında nazal polip tanısı konularak endoskopik sinüs cerrahisi uygulanan 85 hastanın verileri retrospektif olarak incelendi. Tüm hastaların cerrahi öncesi çekilen koronal plan paranazal Bilgisayarlı Tomografi görüntüleri Lund-Mackay ölçülerine göre skorlandı. Patoloji bölümünde, postoperatif nazal polip tanısı alan olguların Hematoksilen-Eosin boyalı preparatları yeniden değerlendirilerek klinik ve radyolojik bulgular ile karşılaştırıldı. Tüm sonuçlar SPSS 13.0 yazılımı kullanılarak analiz edildi. $\mathrm{p}<0.05$ istatistiksel olarak anlamlı kabul edildi.
\end{abstract}

Bulgular: Astımı olan $(\% 16,4)$ ve olmayan $(\% 83,6)$ hastalar histopatolojik açıdan kıyaslandığında eosinofil, lenfosit, nötrofil, makrofaj, mast hücreleri ve goblet hücresi/epitel hücresi oranlarında anlamlı bir fark bulunamadı ( $\mathrm{p}>0.05)$. Lund-Mackay skoru ile hastaların preoperatif şikayetlerinin süresi arasında anlamlı ilişki saptandı $(\mathrm{r}=0,270, \mathrm{p}=0,012)$. Metaplazi bulunan hastaların preparatlarında gözlenen nötrofil sayısı $(16,53 \pm 19,87)$ metaplazi bulunmayan $(8,71 \pm 23,98)$ hastalardan daha yüksek bulundu ( $\mathrm{p}=0,001)$. Radyolojik olarak Lund-Mackay skoruna gore ön ve arka grup sinüslerin tutulumları ile nazal kavitenin tutulumu da paralellik gösterdi.

Sonuç: Preoperatif şikayet süresi ile skuamöz metaplazi varlı̆̆ı ve total Lund-Mackay skorlaması arasında pozitif korelasyon saptandı. Ön ve arka grup sinüslerin polip dokuları arasında histopatolojik olarak fark görülmedi.

Anahtar Sözcükler: Nazal polipler, Patoloji, Eozinofiller, Tomografi

Correspondence: Ercan AKBAY

Mustafa Kemal Üniversitesi Tip Fakültesi, Kulak Burun Boğaz Anabilim Dalı, HATAY, TURKEY

E-mail: ercanakbay@yahoo.com Phone: +90 3262101900 


\section{INTRODUCTION}

Nasal polyposis (NP) is a chronic inflammatory disease originating mainly in the ethmoid sinus (1). The disease has been known for more than 3000 years and is the most common reason for a nasal cavity mass. The incidence, which increases as the age of the population studied increases, is about $2 \%-4 \%$ (2). This mass is the prolapse of inflamed mucosa within the nose, and can be pediculated with a smooth surface, gelatinoid, spherical, or in the shape of grape. The incidence in males is twice that in females. Several mechanisms have been proposed for the formation of nasal polyps. These mechanisms include allergy, infection, enzyme abnormality, mechanical obstruction, autonomic imbalance, abnormal transepithelial ion transport, and epithelial rupture (3). Allergic and inflammatory theories regarding the etiopathogenesis are particularly emphasized. Aspirin-sensitive asthma (ASA) also known as "aspirin triad" (nasal polyposis, asthma, and sensitivity to aspirin) is a well-recognized clinical entity. The management of nasal polyps remains primarily medical, with oral and topical nasal steroids (3). Even though there are medical and surgical treatment options, relapses have been reported.

Radiological Scoring: The Lund-Mackay scoring is a system of grading changes in Computerized Tomography (CT) scans of patients with chronic rhinosinusitis (4). This system relies on a score of $0-2$ that is assigned based on the absence, partial, and complete opacification of each sinus and reaching the ostiomeatal complex, deriving a maximum total score of 12 for both sides $(4,5)$. In this study, we re-scaled the Lund-Mackay scoring of the nasal cavity to a 1-3 point-scale. In this new modified scale, no opacification in the cavity is equal to " 0 "; opacification limited to the ostiomeatal complex, and opacification upon the inferior turbinate are equal to "1"; opacification extending under the inferior turbinate, but not reaching to nasal base is equal to " 2 "; and lastly, opacification reaching the nasal base is equal to " 3 " points. In this study, the LundMackay scoring system produced a maximum score of 13 per side of nasal cavity. Considering only the nasal cavity, the total Lund-Mackay score for both sides is 6 points.

The number of epithelial mast cells in nasal polyp is high (6). Most of the polyp surface area is covered by a ciliated pseudostratified epithelium. However, while a transitional and squamous epithelium is found, squamous metaplasia is not found in ordinary polyp tissue. Gross epithelial defects do not seem to appear in polyp specimens. The glands of NP differ markedly from normal nasal glands. NP's glands are long, tubular, and of varying shape, size, and type. Their density is at least 10 times less than the density in the normal nasal mucosa. Pathologic studies show major variations in both types of epithelium and goblet cell density in different locations on a single polyp (2). In inflammatory polyps, neutrophils are observed in large numbers. In allergic polyps, eosinophils are observed more than the other cells. However, lymphocytes can be observed in chronic sinusitis, especially with NP.

Many studies have reported inflammatory cells in nasal polyps (2,7-9). However, very few studies simultaneously analyzed eosinophils, neutrophils, lymphocyte, and epithelial metaplasia in nasal polyps $(10,11)$. There are some studies in the literature considering the correlation between symptoms and radiological findings or clinical measures and histopathological findings for patients with chronic rhinosinusitis (12-14).

Preoperative CT scan was performed before the surgery and sinonasal distribution assessment with the Lund-Mackay score system, (5). The diagnosis of the postoperative surgical sample was NP as identified during the archive scanning conducted at the pathology department. To detect the presence of mucosal inflammation and cellular, epithelial, and stromal design we carried out a histopathological review. Finally, the goal of this study was to evaluate the relationships between the preoperative Lund - Mackay score and histopathological findings in NP.

\section{MATERIAL and METHODS}

Clinical Evaluation: We randomly selected the participants among patients with sinonasal polyp who had undergone endoscopic sinus surgery in our clinic within the last five years. Then, we retrospectively evaluated them. We noted the patients' clinical findings, ages, gender distribution, systemic diseases, and accompanying sinonasal pathologies. Preoperative CT scans of the patients were examined and scored. The pathology preparations were re-evaluated and the correlations between the pathological, radiological and clinical findings were determined.

Histopathological Evaluation: The surgical materials diagnosed as NP from 2005 to 2010 were identified during the archive scanning conducted at the Pathology Department of Mustafa Kemal University. Eighty-five patients were included within the scope of the study. The $\mathrm{H} \& \mathrm{E}$ stained preparations of the biopsy materials were re-evaluated. The pathologist reviewed the samples while blinded to all clinical and radiological data via the method used by Soler et al. (12). An eyepiece micrometer (ZA3262, U-OCMC, $24 \mathrm{~mm}$ cross, 10/100X) was mounted within one of the eyepiece objectives. At 400X power the field is 0.44 $\mathrm{mm} \times 0.44 \mathrm{~mm}$, yielding an area of approximately $0.19 \mathrm{~mm}^{2}$. 
Histopathological review was performed to assess the presence of mucosal inflammation including cellular, epithelial, and stromal markers (Figure 1A,B). The exact amount of eosinophils, neutrophils, lymphocytes, mast cells, plasma cells, and macrophages were evaluated as cellular markers. The most dense cellular infiltrate was selected for each specimen and each cellular marker was counted as an absolute number at $400 \mathrm{X}$ power in five fields. The presence of squamous metaplasia and goblet cells were evaluated as epithelial markers. Goblet cells were quantified at $400 \mathrm{X}$ as a percentage of epithelial cells within a $0.44 \mathrm{~mm}$ length mucosal fragment. The epithelial lining was scanned for the presence and degree of squamous metaplasia. The scoring was accomplished by using a Likert scale from 0 to 3 with $0=$ not present, $1=$ focal $/$ mild, $2=$ patchy $/$ moderate, and $3=$ extensive/marked. Subepithelial edema and fibrosis were also assessed as stromal markers and scaled by a Likert scale from " 0 " to " 3 " with $0=$ not present, $1=$ focal $/ \mathrm{mild}$, $2=$ patchy/moderate, and $3=$ extensive/marked. Dysplasia was detected in none of the patients.

Radiological Evaluation: All the related screenings of the patients were conducted in the same clinic using the same devices. CT scanning was carried out by a Toshiba Aquilion64 system at $120 \mathrm{KV}$ and $75 \mathrm{~mA}$ with $5 \mathrm{~mm}$ intervals and a gantry tilt, in 2-second interval and in the coronal plane (Bone window: $\mathrm{WW}=2700, \mathrm{WL}=350$ ).

All patients underwent preoperative paranasal sinus CT scan in the coronal plane and the CT images were adapted to Lund-Mackay scores. We evaluated the polypoid infiltration of the nasal cavity by using Lund-Mackay scoring. We assigned zero point for cases in which polyp tissue did not involve the nasal cavity; we assigned one point when nasal tissue held the ostiomeatal complex, but did not hold the sub-concha. Failure to reach nasal base although the inferior turbinate was involved was represented by 3 points. The nasal cavity was scored as at most 6 points for each side. We obtained a numerical "total Lund-Mackay score" by summing the left and right nasal cavity scores and dividing by two. This numerical quantity served as a base for comparing pathological data and intranasal clinical findings.

We separately evaluated the maxillary, frontal, sphenoid, anterior ethmoid and posterior ethmoid sinus cells, and assigned three different points for every sinus. When the polyp tissue did not infiltrate the sinus, a "0" point was assigned. "1" point was given in the case that the polyp tissue infiltrated the sinus, but did not fill itcompletely. Finally, "2" points were designated for the situation when the tissue was completely infiltrated. We graded the right and left nasal cavities and the right and left sinuses separately. We also grouped the sinuses as anterior and posterior. Maxillary, frontal, and anterior ethmoid sinuses constituted the anterior group; posterior ethmoid, and sphenoid sinuses composed the posterior group. Dividing the sum of 6 bilateral anterior groups' sinus points by 6 , we obtained "the average point of anterior group sinus". In the same manner, we summed 4 posterior sinus points and divided by 4 to get "the average point of posterior group sinuses". To compare the radiological grading and histopathological findings of both anterior and posterior group sinuses we used these average points.

Statistical Analysis: Data were collected with the Excel Microsoft software program and all the results were analyzed using the SPSS 13.0 software. Continuous variables
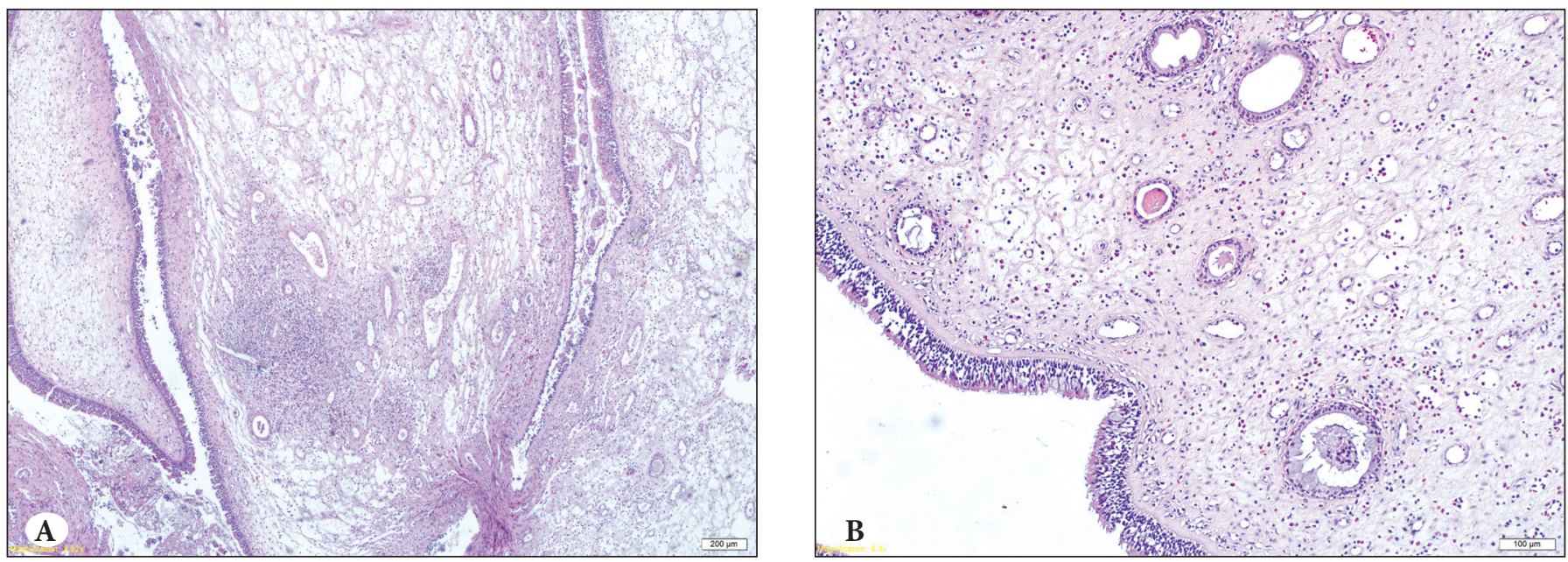

Figure 1: (A) Polypoid lesion with edema, inflammatory cell infiltrate rich with eosinophils, mononuclear cells and goblet cells in the surface epithelium (HE x40), (B) High power view of the polypoid lesion seen in Figure 1A (HEx100). 
were analyzed by the Kolmogorov-Smirnov test in terms of normal distribution. The Mann-Whitney $U$ test was used to compare differences between the groups, and Spearman correlation test was run to see the relationship between the continuous variables. Linear regression analysis was used to compare the effects of the means of anterior and posterior sinus groups on Lund-Mackay scores. Statistical significance was determined as $\mathrm{p}<0.05$.

\section{RESULTS}

The average age of the patients diagnosed as NP including 54 (63.5\%) males and 31 (36.5\%) female (total 85 patients) was $38.05 \pm 16.64$ (min. 11 - max. 70) years. Besides their main diagnosis, we determined the accompanying sinonasal pathologies. Two of the patients had aspirin hypersensitivity; 1 of them had adenoid vegetation; 1 of them was suffering from osteoma of frontal sinus; 1 had fungal sinusitis; and 1 patient had rhinolithiasis. Once we examined them for systemic diseases, we saw that 60 (70.6\%) of them did not have any kind of systemic disease; however, 10 had bronchial asthma, 4 had diabetes mellitus, 3 had hypertension, 4 had asthma and hypertension, 3 had diabetes mellitus and hypertension, and 1 patient was diagnosed with Kartagener's syndrome.

The time-interval calculated for preoperative complaint was $63.17 \pm 51.14$ (min. 2 - max. 240) months; and the average number of previously surgeries was $0.45 \pm 1.01$. The maximum number of surgeries performed on a patient was counted as 5 operations. The mean of the sum of bilateral Lund-Mackay scores with respect to nasal cavity polypoid involvement was $4.21 \pm 1.44$ out of 6 . Once the sinuses were categorized into anterior and posterior; anterior sinus involvement for each sinus was determined as an average of $1.10 \pm 0.62$ out of 2 ; similarly the average for each sinus of posterior sinus involvement was $0.69 \pm 0.71$ out of 2 .

Considering the age and gender, neither radiological nor pathological findings revealed a difference. Nonetheless, the male/female ratio was close to the general data corresponding with the NP diagnosis (54/31).
Histopathologically, average rates of eosinophil, neutrophil, lymphocyte, macrophage, mast cells and goblet cells over epithelial cells were obtained respectively as $32.95 \pm 38.51$ (min. 0 - max. 160), 11.10 22.9 ( $\min .0$ - $\max .160$ ), 49.72 \pm 34.76 (min. 10 - max. 150), $0.43 \pm 0.66(\min .0-\max$. 3), $1.47 \pm 1.88$ (min. 0 - max. 8), $0.18 \pm 0.17$ ( $\min .0-\max$. 0.78) (Table I). Fifty-nine (69.4\%) patients did not have squamous metaplasia (not present); however, 13 (15.33\%) of them were +1 (focal / mild) positive; $10(11.8 \%)$ were +2 (patchy/moderate) positive; and $3(3.5 \%)$ were +3 (extensive/marked) positive. The other parameters of epithelial data are presented in the table (Table II).

In the statistical comparison of $14(16.4 \%)$ patients with bronchial asthma and 71 (83.6\%) without bronchial asthma, there was no statistical significance with respect to eosinophil, lymphocyte, neutrophil, macrophage, mast cell and goblet cells / epithelial cells rate ( $>0.05)$. The comparison of these same groups' radiological data also showed no statistically significant difference with respect to the Lund-Mackay scores ( $\mathrm{p}=0.169$ ).

We have observed a positive relationship between the preoperative complaint period and total Lund-Mackay scores $(\mathrm{r}=0.270, \mathrm{p}=0.012)$ (Figure 2$)$. We have also seen that averages of both anterior and posterior group sinuses' radiological scores were parallel to average Lund-Mackay

Table I: Average rates of cellular dispersion of NP: At 400X power the field is $0.44 \mathrm{~mm} \times 0.44 \mathrm{~mm}$, yielding an area of approximately $0.19 \mathrm{~mm}^{2}$ histologically. The densest cellular infiltrate in each case at $400 \mathrm{X}$ power was obtained and each cellular marker was counted as an absolute number

\begin{tabular}{|l|c|c|c|c|}
\hline Cells & Min. & Max. & Mean & Std. Dev. \\
\hline Eosinophil & 0 & 160 & 32.95 & 38.51 \\
\hline Neutrophil & 0 & 160 & 11.10 & 22.97 \\
\hline Lymphocyte & 10 & 150 & 49.72 & 34.76 \\
\hline Macrophage & 0 & 3 & 0.43 & 0.66 \\
\hline Mast cell & 0 & 8 & 1.47 & 1.88 \\
\hline
\end{tabular}

Table II: Distribution of subepithelial edema and fibrosis were assessed by using a Likert scale from 0 to $3(0=$ not present, $1=$ focal $/ \mathrm{mild}$, $2=$ patchy/moderate, and $3=$ extensive/marked)

\begin{tabular}{|l|c|c|c|c|}
\hline & No Edema & Focal Edema & Patchy Edema & Extensive Edema \\
\hline Frequency/Patient & $3 / 85$ & $24 / 85$ & $38 / 85$ & $20 / 85$ \\
\hline Percent & $3.5 \%$ & $28.2 \%$ & $44.7 \%$ & $23.5 \%$ \\
\hline & No Fibrosis & Focal Fibrosis & Patchy Fibrosis & Extensive Fibrosis \\
\hline Frequency/Patient & $36 / 85$ & $45 / 85$ & $4 / 85$ & $0 / 85$ \\
\hline Percent & $42.4 \%$ & $52.9 \%$ & $4.7 \%$ & $0.0 \%$ \\
\hline
\end{tabular}


scores of the nasal cavity (Table III). This finding shows that nasal cavity polyps and sinus polyps grow in correlation. In this study it was also observed that anterior group cells were infiltrated more than posterior group cells (Figure 3).

Looking at the Lund-Mackay scoring and average sinus scoring, the neutrophil increase was significant. On the other hand, no significant difference determined for other inflammatory cells, epithelial cells, sub-mucosal fibrosis raise, goblet cell / epithelial cell rate.

We also compared the patients with and without metaplasia based on their pathological examination with respect to other pathological findings; and no significant result was drawn for eosinophil, lymphocyte, macrophage, mast cell, goblet cell / epithelial cell rate $(\mathrm{p}>0.05)$. Preoperative complaint period of the patients with metaplasia was longer $(80.11 \pm 57.08$ months) than of those without metaplasia (55.71 \pm 46.88 months) $(\mathrm{p}=0.03)$. The neutrophil amount $(16.53 \pm 19.87)$ on the preparation of the patients with metaplasia was also higher than the neutrophil amount $(8.71 \pm 23.98)$ on the preparation of the patients without

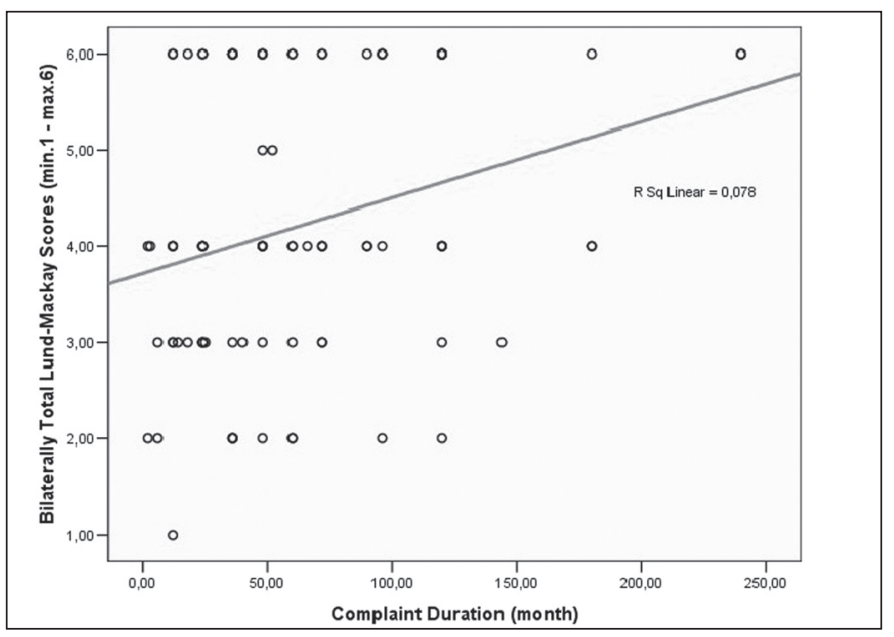

Figure 2: Positive correlation between the complaint duration of patients and Lund-Mackay score. metaplasia $(\mathrm{p}=0.001)$. Considering the metaplasia, we could not specify any meaningful relation between other inflammatory and allergic cells.

From the radiological aspect, by looking at the polypoid tissue distribution of the patients with and without the squamous metaplasia, neither Lund-Mackay scoring nor anterior-posterior sinus polypoid involvements suggested a significance difference.

\section{DISCUSSION}

NP can be defined as chronic inflammatory disease of a paranasal sinus and especially the nasal mucosa (7). The most severe form of chronic rhinosinusitis is nasal polyposis (8). A variety of inflammatory cells may be found inside the polypoid tissue, in the mucus or nasal mucosa. This study was designed to find out the correlation between clinical findings, preoperative CT scan's opacification and their histopathologic findings.

$\mathrm{NP}$ is common between the ages of $40-70$ years and is predominant in males with a ratio of 2:1 (15). In our study,

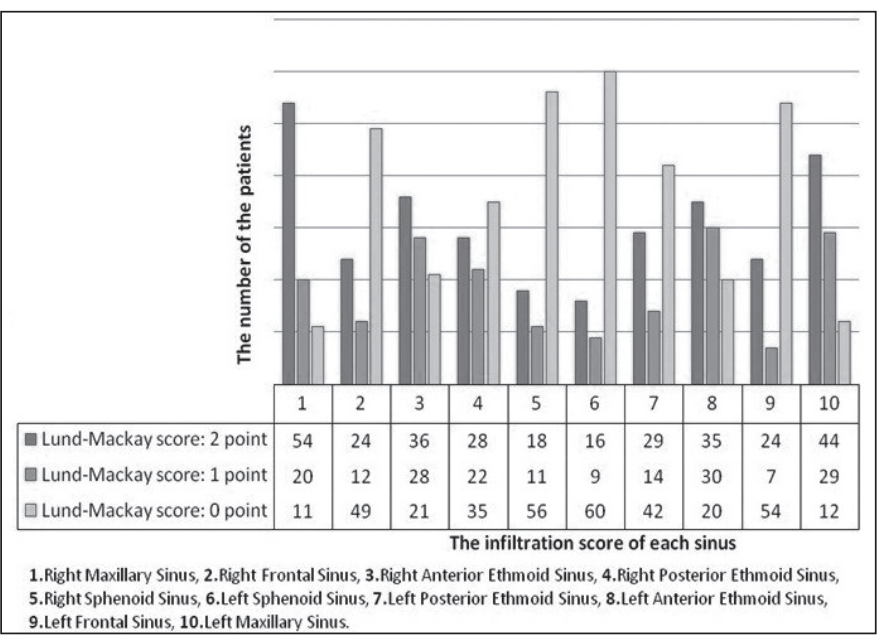

Figure 3: CT findings of each one sinus' polypoid involvement by the Lund-Mackay system: It is observed that polyps tend to mostly involve the maxillary sinuses, least the sphenoid sinuses.

Table III: (a) Dependent Variable: Total Score of Lund-Mackay. ${ }^{(b)}$ Positive correlation between Lund-Mackay score of nasal cavity and infiltration of anterior-posterior sinuses by the polyp tissues

\begin{tabular}{|c|c|c|c|c|c|c|c|}
\hline \multicolumn{8}{|c|}{ Coefficients $^{(\mathrm{a})}$} \\
\hline \multirow[t]{2}{*}{ Model } & \multicolumn{2}{|c|}{$\begin{array}{l}\text { Unstandardized } \\
\text { Coefficients }\end{array}$} & \multirow{2}{*}{$\begin{array}{c}\begin{array}{c}\text { Standardized } \\
\text { Coefficients }\end{array} \\
\text { Beta }\end{array}$} & \multirow[t]{2}{*}{$\mathbf{t}$} & \multirow[t]{2}{*}{ Sig. } & \multicolumn{2}{|c|}{ 95\% Confidence Interval for B } \\
\hline & B & Std. Error & & & & Lower Limit & Higher Limit \\
\hline \multirow{3}{*}{$\begin{array}{l}\text { (Constant) } \\
\text { Anterior Cell's Mean Score } \\
\text { Posterior Cell's Mean Score }\end{array}$} & 2.760 & .261 & & 10.590 & .000 & 2.241 & 3.278 \\
\hline & 1.045 & .293 & .449 & 3.570 & .001 & .463 & 1.627 \\
\hline & .433 & .254 & .215 & 1.707 & .092 & -.072 & .938 \\
\hline
\end{tabular}


like the literature data, $63.5 \%$ of the patients were male and the mean age was $38.05 \pm 16.64$ (11-70) years.

NP's are mainly located in the middle meatus, maxillary sinus, frontal recess; and originate from the nasal mucous membrane ostia in the paranasal sinus $(2,16)$. In this study, regarding Lund-Mackay scores, it is inferred that polyp tissues more often infiltrate the anterior sinuses, maxillary sinuses, and nasal cavity's ostiomeatal complex areas than other areas.

NP is often observed with other disorders such as cystic fibrosis, asthma, ASA hypersensitivity, Kartagener's syndrome, Young syndrome and diabetes mellitus. In this study, 60 (70.6\%) patients did not have any kind of systemic disease; however, 10 of them were diagnosed as bronchial asthma, 4 of them had diabetes mellitus, 3 patients had hypertension, 4 of them asthma and hypertension, 3 diabetes mellitus and hypertension, and 1 patient was diagnosed with Kartagener's syndrome.

The association between asthma and NP has been revealed since the 19th century (17). The exact cause of this relation is still not well understood. According to an epidemiologic standpoint, the frequency of polyps ranges between $10 \%$ and $15 \%$ in asthmatic patients (18). However, the foregoing report shows that the frequency of asthma in the setting of NP is between $30 \%$ and $70 \%$. As for our study, only 14 (16.4\%) out of 85 patients had asthma. Asthma symptoms were assessed using objective measures, specifically pulmonary function testing and steroid usage data. Haro et al., by using the Lund-Mackay system in their study, found the average score of 10.9 in the tomographic evaluation of non-asthmatic patients; yet, they found the average score of 17.6 in the tomography of asthmatic patients. There was statistical significance between asthmatic and nonasthmatic patients (19). There was no correlation between the stages of NP and the presence of asthma as also reported by Garrel et al (20). Moreover, our study also did not show clinical and radiological stage difference between the patients with and without asthma.

Patients with cystic fibrosis and patients with primary cilliary dyskinesia (Kartagener's syndrome) frequently develop NP (2). The polyps associated with these diseases are not characterized by tissue eosinophilia but characterized by lymphocytes in the tissue and neutrophils in the secretion (21). Only one patient was diagnosed with Kartagener's syndrome in this study. For this particular patient, opacification was observed within all sinuses and the bilateral nasal cavity with the CT scans. Regarding the pathological examination; there were 20 lymphocytes in every unit square (specified in the material and method section). We did not observe other inflammatory cells in this study. There is no study on the comparison of the clinical, radiological, and histopathological data in patients with NP. Soler et al. showed that mucosal eosinophilia correlated with objective disease severity as defined by CT for patients with chronic sinusitis. The other inflammatory cells did not correlate with CT scans in that study (12). In this study, with respect to Lund-Mackay scores, we found that all inflammatory cells including eosinophilia were not correlated with CT scanning. Eosinophils are crucial effector cells in the inflammatory reactions associated with asthma, allergic inflammatory disease, parasitic diseases, granulomatous disorders, fibrosis and several sinonasal diseases $(7,8)$. Since all of the patients in our study had NP, we compared the patients according to presence of asthma and there was no difference between two groups in terms of eosinophil levels.

Number of neutrophil cells for patients with and without metaplasia differed. Neutrophils are the markers found in the higher numbers with acute inflammatory cases. However, metaplasia may occur as a result of chronic irritation. Considering these facts, it could be inferred that metaplasia occurs in recurrent acute inflammatory phase rather than chronic period. The time duration until making the final decision for an operation for those patients with metaplasia turned out to be longer than of those patients without having metaplasia. This result shows that metaplasia comes into existence in a long period of time. We also uncovered that metaplasia does not depend upon Lund-Mackay scores.

Baird et al., in a short period of time such as eight months, showed the existence of atypia in fifteen nasal polypectomy specimens containing squamous metaplasia (22). The study shows that preoperative complaint period of patients with metaplasia is longer than those without metaplasia. Furthermore, the number of neutrophils in cases that have metaplasia was higher than of those without metaplasia. No dysplasia was determined for any preparation. We did not detect any signs of dysplasia in any patient in our study as in this report.

\section{CONCLUSION}

Sinonasal polyps represent a diffuse (especially extending to the anterior group sinus and anterior nasal cavity) inflammatory process that probably has multiple causes. No correlation between Lund-Mackay scoring and pathological findings was determined in this study. Positive correlations were stated between preoperative complaint 
period and squamous metaplasia, and the preoperative complaint period and Lund-Mackay scoring. Looking at this result, a meaningful correlation between Lund-Mackay score and metaplasia might be expected to exist; however, no statistically significant correlation was identified. This result could also be affected by the small sample size. No histopathological difference was found between polypoid tissues of anterior group and posterior group sinuses.

\section{REFERENCES}

1. Dufour X, Bedier A, Ferrie JC, Gohler C, Klossek JM: Diffuse nasal polyposis and endonasal endoscopic surgery: Long-term results, a 65-case study. Laryngoscope 2004, 114:1982-1987

2. Mygind N, Dahl R, Bachert C: Nasal polyposis, eosinophil dominated inflammation, and allergy. Thorax 2000, 55:79-83

3. Assanasen P, Naclerio RM: Medical and surgical management of nasal polyps. Curr Opin Otolaryngol Head Neck Surg 2001, 9: 27-36

4. Mortuaire G, Bahij J, Maetz B, Chevalier D: Lund-Mackay score is predictive of bleeding in ethmoidectomy for nasal polyposis. Rhinology 2008, 46:285-288

5. Lund VJ, Mackay IS: Staging in rhinosinusitis. Rhinology 1993, 31:183-184

6. Ruhno J, Howie K, Anderson M, Andersson B, Vanzieleghem M, Hitch D, Lapp P, Denburg J, Dolovich J: The increased number of epithelial mast cells in nasal polyps and adjacent turbinates is not allergy-dependent. Allergy 1990, 45:370-374

7. Shin SH, Lee SH, Jeong HS, Kita H: The effect of nasal polyp epithelial cells on eosinophil activation. Laryngoscope 2003, 113:1374-1377

8. Eliashar R, Levi-Schaffer F: The role of the eosinophil in nasal diseases. Curr Opin Otolaryngol Head Neck Surg 2005, 13: 171-175

9. Wise SK, Ahn CN, Schlosser RJ: Localized immunoglobulin E expression in allergic rhinitis and nasal polyposis. Curr Opin Otolaryngol Head Neck Surg 2009, 17:216-222

10. Morinaka S, Nakamura $\boldsymbol{H}$ : Inflammatory cells in nasal mucosa and nasal polyps. Auris Nasus Larynx 2000, 27:59-64

11. Van Drunen CM, Reinartz S, Wigman J, Fokkens WJ: Inflammation in chronic rhinosinusitis and nasal polyposis. Immunol Allergy Clin North Am 2009, 29:621-629

12. Soler ZM, Sauer DA, Mace J, Smith TL: Relationship between clinical measures and histopathologic findings in chronic rhinosinusitis. Otolaryngol Head Neck Surg 2009, 141:454-461

13. Basu S, Georgalas C, Kumar BN, Desai S: Correlation between symptoms and radiological findings in patients with chronic rhinosinusitis: An evaluation study using the Sinonasal Assessment Questionnaire and Lund-Mackay grading system. Eur Arch Otorhinolaryngol 2005, 262:751-754

14. Moghadasi H, Saneei Taheri M, Vazir Nezami M, Mohammadpour H, Jalali AH, Delavari H, Peyravi Chashnasar M: Association between clinical symptoms and CT findings in chronic rhinosinusitis. Iran J Radiol 2008, 5:145-149
15. Dursun E, Samim E, Korkmaz H, Bayızü, Uygur K, Akmansu H, Özeri C: Nazal polipozisli olgularda endoskopik sinüs cerrahisi. KBB ve BBC Dergisi 1998, 6:71-80

16. Larsen PL, Tos M: Origin of nasal polyps: An endoscopic autopsy study. Laryngoscope 2004, 114:710-719

17. Uri N, Cohen-Kerem R, Barzilai G, Greenberg E, Doweck I, Weiler-Ravell D: Functional endoscopic sinus surgery in the treatment of massive polyposis in asthmatic patients. J Laryngol Otol 2002, 116:185-189

18. Batra PS, Kern RC, Tripathi A, Conley DB, Ditto AM, Haines GK 3rd, Yarnold PR, Grammar L: Outcome analysis of endoscopic sinus surgery in patients with nasal polyps and asthma. Laryngoscope 2003, 113:1703-1706

19. Haro JI, Gavioli F, Junior VM, Crespo CC: Clinical aspects of patients with nasal polyposis. Int Arch Otorhinolaryngol 2009, 13:259-263

20. Garrel R, Gardiner Q, Khudjadze M, Demoly P, Vergnes C, Makeieff M, Guerrier B, Crampette L: Endoscopic surgical treatment of sinonasal polyposis-medium term outcomes (mean follow-up of 5 years). Rhinology 2003, 41:91-96

21. Sorensen H, Mygind N, Tygstrup I, Winge Flensborg E: Histology of nasal polyps of different etiology. Rhinology 1977, 15:121-128

22. Baird AR, Hilmi O, White PS, Robertson AJ: Epithelial atypia and squamous metaplasia in nasal polyps. J Laryngol Otol 1998, 112:755-757 